\title{
THERMAL ASSESSMENT FOR PROSTHESES: STATE-OF-THE-ART REVIEW
}

\author{
SAHAR A. ABBOOD, ZAN WU \& BENGT SUNDÉN \\ Department of Energy Sciences, Lund University, P.O. Box 118, Lund SE-22100, Sweden.
}

\begin{abstract}
Hundreds of young people have had limbs amputated after being wounded by civil wars, explosions or gunshots. Heat and perspiration within a prosthetic socket are the most common side effects of reduced quality life for prosthesis. Besides, the environment between liner and skin is an ideal host of residual limb skin problems such as contact dermatitis and bacterial infections. It is important to minimize the limiting heat transfer to improve amputee safety and comfort. Usually, when there is a skin problem, the treatment requires the amputee not to wear his/her prosthesis for an extended period of time. This functional loss can adversely affect the amputee's physical, mental and emotional well-being. This work aims to highlight a number of important issues concerning the effect of thermal conditions on prosthetics to shed light on new design methods for prosthetics.
\end{abstract}

Keywords: heat transfer, liner, prostheses, thermal conditions.

\section{INTRODUCTION}

The number of limb amputations is increased due to various reasons, e.g, vascular diseases and trauma, in the whole world. These patients need to use prostheses in their daily life activities. Figure 1 shows different types of amputations.

An amputee patient is generally fitted with a prosthesis in order to help the patient return to the state of life prior to amputation. A prosthesis, in medicine, is an artificial device that replaces a missing part. Figure 2 shows the parts of a prosthesis for an above-knee amputation. The liner component of the prosthesis contacts with the residual limb directly. The main functions of which are load distribution, friction reduction and cushioning around the residual limb [1]. Liners are now primarily made of an outer fabric layer and an inner elastomeric layer, which usually is either silicone, a thermoplastic elastomer, or polyurethane [1]. The prosthetic socket is made of rigid plastic, which is designed specifically for the patient to fit the liner around the residual limb optimally.

It is hard for thermoregulation to appropriately regulate the temperature of a residual limb as the associated heat transfer mechanisms are compromised in the residual limb. Convective heat transfer of the whole body is also compromised as there is less surface area available due to the loss of a limb [4]. Thermal discomforts are side effects of prosthesis used in hot, cold and humid environments. As the prosthesis is made of insulating materials, it limits heat transfer and perspiration, resulting in stump skin injuries. Combined with perspiration, the environment between the liner and skin is a perfect host of residual limb skin problems including contact dermatitis, hyperhidrosis and bacterial infections as shown in Figure 3. The main reason for these skin problems is the unfavourable thermal environment around the residual limb which traps heat and inhibits sweat from evaporating away from the residual limb.

The skin is prone to problems when the skin is exposed to unnatural circumstances. Perry et al. [5] revealed that a temperature increase of $1-2^{\circ} \mathrm{C}$ in residual limb skin temperature inside the prosthetic socket could cause discomfort. Thermal comfort is a general sense of the body that would be disturbed in the presence of limb temperature imbalance [6]. The skin 


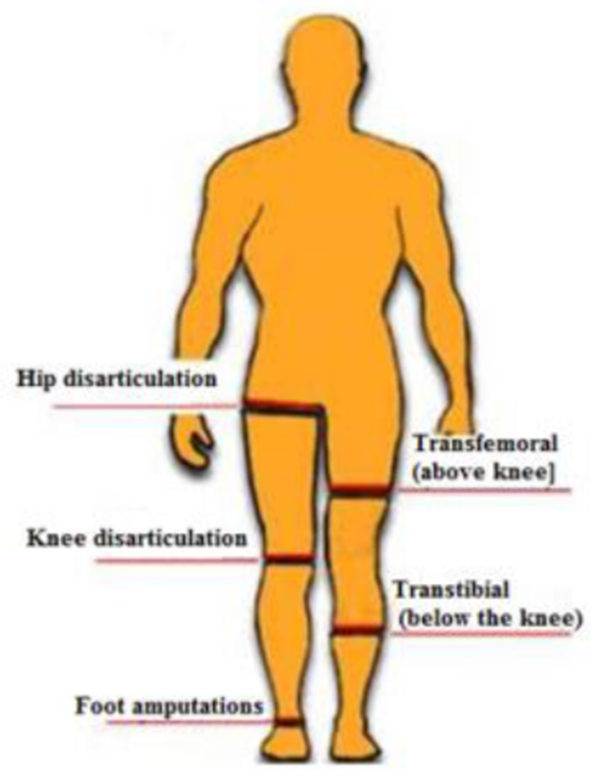

Figure 1: Different types of amputations [2].

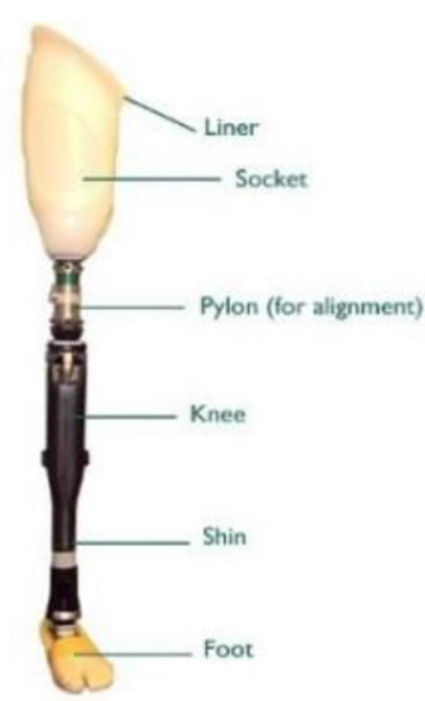

Figure 2: The parts of a prosthesis [3].

produces water, gases and various compounds, as investigated by Barnes [7]. A health paper was proposed by Branemark and Hagberg [8] to increase the quality of life-long prosthesis use. This study was carried out in Sweden. About $82 \%$ of the patients used prostheses daily. The results showed that the most frequent problems leading to reduction in the quality of prosthesis life were heat/sweating in the prosthetic socket and sores/skin irritation. The study recommended continued investigations to test new socket materials to improve prostheses. Hachisuka et al. [9] investigated the moisture permeability properties of liner and socket materials (including a silicon liner, Degaplast plastic and a sample of a popular wooden socket). They found that the wooden socket was about four times as permeable as the other materials. A questionnaire was performed by Meulenbelt et al. [10] to identify determinants of skin problems in lower limb amputees. The study covered patients from different ages and gender. The results of using sockets in activities showed that the most frequent skin problems
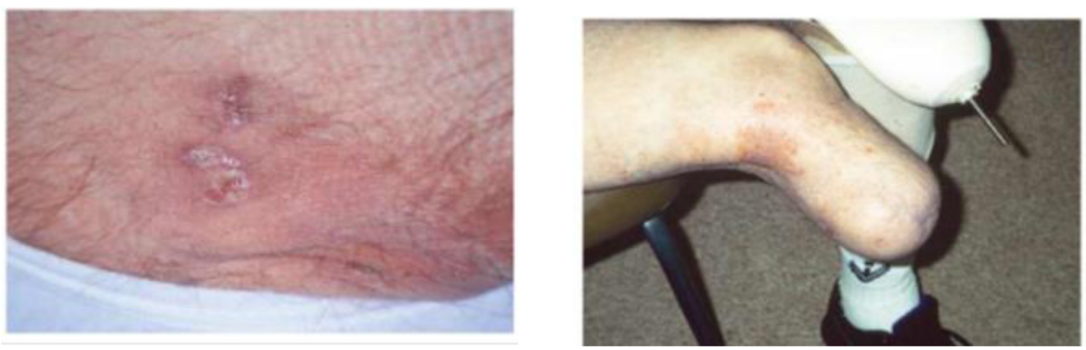

Figure 3: Epidermoid cysts in groin skin with above knee and atopic eczema with below knee prosthesis [12]. 
were profuse sweating (32\%), redness of skin more than 1 minute after removing the prosthesis $(29 \%)$ and sensitive skin $(23 \%)$. Skin problems common in patients who used the prosthesis might also cause mental, social and economic distress for patients. Koc et al. [11] recommended that early recognition and treatment might mitigate these problems.

\section{THERMAL CONDUCTIVITY OF PROSTHETICS SOCKETS AND LINERS}

Conductive heat transfer through the component layers of the prosthesis is likely one of the main heat transfer mechanisms for heat dissipation from the residual limb to the environment. Due to the relatively low thermal conductivity values of the component layers, conductive heat transfer is thought to be limited. Not so much is known about the thermal conductivity of the current generation of prosthetic components. This section will briefly describe methods for thermal conductivity measurements and thermal conductivity values for prosthetic sockets and liners reported in the literature.

One method is to measure the heat flow from a hot surface, through a material of interest, to a cold surface, as shown in Figure 4a. A uniform temperature differential is maintained by setting temperatures of the hot and cold plates. The thermal conductivity $(k)$ can be calculated using the Fourier law for steady state heat conduction for constant area:

$$
k=\frac{q L}{A \Delta T} .
$$

When $\Delta T$ is the temperature differential $(\mathrm{K}), q$ is heat flux $\left(\mathrm{W} / \mathrm{m}^{2}\right), L$ is the thickness of the sample $(\mathrm{m})$ and $A$ is the area of the sample $\left(\mathrm{m}^{2}\right)$ respectively. Another method is the Transient Plane Source (TPS) technique, which is designed for convenient thermal conductivity and thermal diffusivity measurements on various samples. The Hot Disk probe (Hot Disk AB, Sweden) comprises a flat sensor with a continuous double-spiral of electrically-conducting nickel (Ni) metal etched out of thin foil and sandwiched between two layers of Kapton or Mica [13]. The Hot Disk probe operates as both a heat source and temperature sensor. The thin Kapton or Mica layers provide both electrical insulation from the sample and mechanical stability of the probe. The fundamental principle of the TPS method is the Fourier Law of heat conduction. During tests, the sensor is normally placed between the surfaces of two pieces of the sample to be measured, as shown in Figure $4 \mathrm{~b}$. A step-wise heating of the sensor embedded in the test sample results in a local heating of the sample neighborhood. The sensor, the nickel resistance element with a well-defined temperature coefficient of electrical resistance, delivers heat and simultaneously measures the average temperature response of the heating element which results from this local heating process. This transient temperature response is recorded for the whole experimental process. Thermal conductivity, thermal

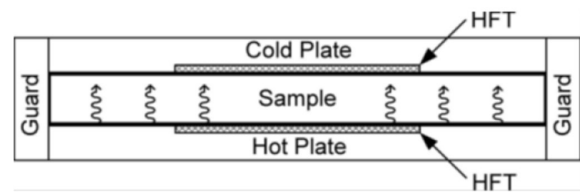

(a) [4]

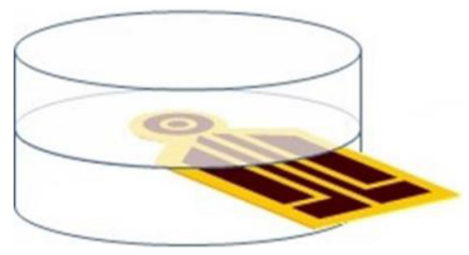

(b) [14]

Figure 4: Examples of thermal conductivity measurement methods. 
diffusivity and volumetric heat capacity can be estimated from the obtained transient temperature response [13].

Klute et al. [4] measured thermal conductivity values of different socket and liner materials, as listed in Table 1 . It can be seen from Table 1 that the thermal conductivity ranged from 0.085 to $0.266 \mathrm{~W} / \mathrm{mK}$ for liner materials and from 0.148 to $0.150 \mathrm{~W} / \mathrm{mK}$ for socket materials.

Experimental results of Webber [1] showed that the thermal conductivity for liners ranged from 0.117 to $0.143 \mathrm{~W} / \mathrm{mK}$, and that for socket materials ranged from 0.133 to $0.189 \mathrm{~W} / \mathrm{mK}$. All materials tested had thermal conductivities substantially less than $1 \mathrm{~W} / \mathrm{mK}$, indicating that they all are insulators.

Table 1: Thermal conductivity of liner and socket materials [4]

\begin{tabular}{|c|c|c|c|c|}
\hline & $\begin{array}{l}\text { Fabric } \\
\text { cover }\end{array}$ & $\begin{array}{l}\text { Thermal } \\
\text { conductivity } \\
\left(\mathrm{W} / \mathrm{m}^{\circ} \mathrm{K}\right)\end{array}$ & $\begin{array}{l}\text { Thickness } \\
(\mathrm{mm})\end{array}$ & $\begin{array}{l}\text { Product } \\
\text { description }\end{array}$ \\
\hline \multicolumn{5}{|l|}{ Liner } \\
\hline Pelite $^{1}$ & $\mathrm{~N}$ & 0.085 & 4.2 & Closed cell foam \\
\hline Syncor, Durasleeve ${ }^{2}$ & $\mathrm{Y}$ & 0.085 & 3.5 & Closed cell foam \\
\hline Bocklite $^{3}$ & $\mathrm{~N}$ & 0.091 & 6.0 & Closed cell foam \\
\hline OWW, Alpha Original $^{2}$ & $\mathrm{Y}$ & 0.114 & 3.0 & Mineral oil gel \\
\hline OWW, Alpha Max ${ }^{2}$ & $\mathrm{Y}$ & 0.128 & 6.0 & Mineral oil gel \\
\hline OWW, P-pod ${ }^{2}$ & $\mathrm{Y}$ & 0.143 & 3.0 & Mineral oil gel \\
\hline OWW, Alpha Spirit ${ }^{2}$ & $\mathrm{Y}$ & 0.155 & 6.0 & Mineral oil gel \\
\hline ALPS, EZLiner HP Fabric ${ }^{2}$ & $\mathrm{Y}$ & 0.164 & 6.0 & Silver in gel \\
\hline Centri, Cushion Liner ${ }^{1}$ & $\mathrm{~N}$ & 0.164 & 3.0 & $\begin{array}{l}\text { Thermoplastic } \\
\text { elastomer }\end{array}$ \\
\hline $\begin{array}{l}\text { Euro International, Contex-Gel } \\
\text { Streifeneder }\end{array}$ & $\mathrm{Y}$ & 0.166 & 6.0 & Polymer gel \\
\hline $\begin{array}{l}\text { Freedom Innovations, Evolution } \\
\mathrm{SP}^{5}\end{array}$ & $\mathrm{~N}$ & 0.181 & 3.0 & $\begin{array}{l}\text { Platinum cured } \\
\text { silicone }\end{array}$ \\
\hline ALPS, VIVA Sleeve ${ }^{2}$ & $\mathrm{Y}$ & 0.182 & 6.0 & Gel \\
\hline Medipro, RELAX ${ }^{2}$ & $\mathrm{Y}$ & 0.182 & 6.0 & $\begin{array}{l}\text { Silicone with } \\
\text { Umbrellan }^{\circledR}\end{array}$ \\
\hline Silipos, Explorer Gel Liner ${ }^{2}$ & $\mathrm{Y}$ & 0.184 & 6.0 & Mineral oil gel \\
\hline ESP, Aegis Streamline ${ }^{2}$ & $\mathrm{Y}$ & 0.187 & 6.0 & Pure silicone \\
\hline ESP, Aegis Streamline ${ }^{2}$ & $\mathrm{~N}$ & 0.189 & 6.0 & Pure silicone \\
\hline Medipro Sensitive $^{2}$ & $\mathrm{Y}$ & 0.194 & 6.0 & Silicone \\
\hline ALPS, VIVA Sleeve HP Fabric ${ }^{2}$ & $\mathrm{Y}$ & 0.202 & 6.0 & Gel \\
\hline Ossur, IeeRoss Dermo Seal-in ${ }^{6}$ & $\mathrm{Y}$ & 0.205 & 6.0 & Dermogel $^{\circledR}$ \\
\hline
\end{tabular}


Table 1: (Continued)

\begin{tabular}{|c|c|c|c|c|}
\hline & $\begin{array}{l}\text { Fabric } \\
\text { cover }\end{array}$ & $\begin{array}{l}\text { Thermal } \\
\text { conductivity } \\
\left(\mathrm{W} / \mathrm{m}^{\circ} \mathrm{K}\right)\end{array}$ & $\begin{array}{l}\text { Thickness } \\
(\mathrm{mm})\end{array}$ & $\begin{array}{l}\text { Product } \\
\text { description }\end{array}$ \\
\hline $\begin{array}{l}\text { Euro International, Silicone } \\
\text { First Class Liner }{ }^{4}\end{array}$ & $\mathrm{Y}$ & 0.212 & 6.0 & Silicone \\
\hline ESP, Aegis Ultimate ${ }^{2}$ & $\mathrm{Y}$ & 0.225 & 6.0 & Pure silicone \\
\hline Ottoboclk, Silicone Liner ${ }^{3}$ & $\mathrm{Y}$ & 0.228 & 3.0 & Silicone gel \\
\hline $\begin{array}{l}\text { Ossur, IceRoss Comfort Plus } \\
\text { Sensil Gel }{ }^{6}\end{array}$ & $\mathrm{Y}$ & 0.266 & 6.0 & $\begin{array}{l}\text { Soft stensil }{ }^{\circledR} \\
\text { silicone gel }\end{array}$ \\
\hline \multicolumn{5}{|l|}{ Socket } \\
\hline Carbon fibre lay-up & & 0.148 & 4.2 & \\
\hline Thermoplastic & & 0.150 & 4.6 & \\
\hline
\end{tabular}

\section{THE EFFECT OF ACTIVITY ON SKIN TEMPERATURE}

Wissler [15] developed a mathematical model to simulate the physical characteristics of the human thermal system at transient state. Physiological parameters such as local metabolic reactions, heat generation rates and blood flow rates of sweating must be specified as input data. The program has been carefully checked for errors, and it is now being used to analyze some problems of current interest. Figure 5 shows the temperature by using the mathematical model. Another mathematical model by Gordon et al. [16] was used for a human regulator system and a finite difference technique was used. Modelling results and direct experimental work were compared for transient cold exposure and it was suggested that the skin heat flux could be an important input to the regulator system. Peery et al. [5] tried to predict the

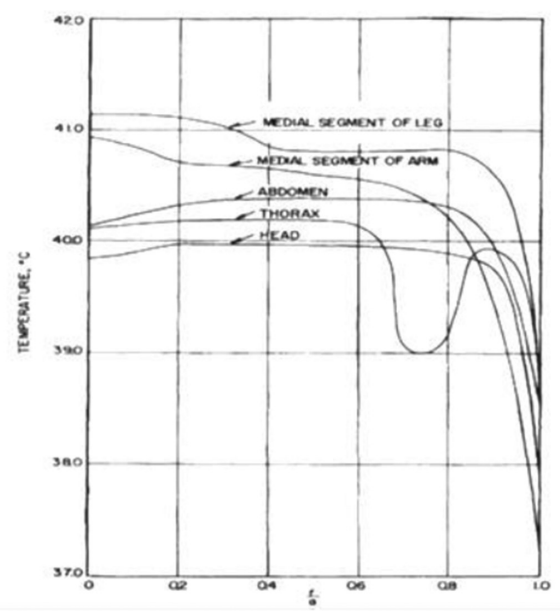

Figure 5: Temperature profiles at the end of the exercise period computed from the mathematical model [15]. 
steady-state skin temperature distribution inside a common prosthetic socket system by using Penne's biological heat transfer (BHT) equation [17]:

$$
\rho c \frac{\partial T}{\partial t}=\nabla k \nabla T+w_{b} \rho_{b} c_{b}\left(T_{b}-T\right)+q_{m},
$$

where $\rho$ is tissue density $\left(\mathrm{kg} / \mathrm{m}^{3}\right), c$ is specific heat $(\mathrm{J} / \mathrm{kgK}), T$ is tissue temperature $(\mathrm{K}), t$ is time $(\mathrm{s}), \nabla$ is the gradient operator, $k$ is thermal conductivity $(\mathrm{W} / \mathrm{mK}), w_{\mathrm{b}}$ is the volumetric rate of perfusion ( $\mathrm{ml} / \mathrm{ml} . \mathrm{s}), T_{\mathrm{b}}$ is arterial blood temperature and $q_{\mathrm{m}}$ is volumetric metabolic heat flow rate $\left(\mathrm{W} / \mathrm{m}^{3} \mathrm{~s}\right)$, respectively.

The results showed that skin temperature was increased when prostheses were donned. High skin temperatures were found near muscle tissue and low temperatures were located at the external and distal end of the residual limb. Numerical and experimental results showed similar trends. Table 2 and Figure 6 show skin temperature versus locations for both numerical and experimental data. They concluded that numerical results could provide the steady-state skin temperature distribution inside the prosthetic socket and might help the design of new prosthetic systems.

Klute and Ledoux [19] studied the effect of different activities on skin temperature. Temperature sensors were fixed on two columns as shown in Figure 7. The temperatures of nine patients' residual limbs were monitored before, during and after the exercise. The results

Table 2: Basal state temperature (mean value \pm standard deviation) for numerical and experimental data [5]

\begin{tabular}{lcc}
\hline Section & Numerical Model Temperature $\left({ }^{\circ} \mathrm{C}\right)$ & Experimental Temperature $\left({ }^{\circ} \mathrm{C}\right)$ \\
\hline Anterior & $31.6 \pm 0.7$ & $31.5 \pm 1.5$ \\
Lateral & $32.9 \pm .05$ & $32.6 \pm 1.5$ \\
Posterior & $32.9 \pm 0.6$ & $32.7 \pm 1.6$ \\
Medial & $32.0 \pm 0.7$ & $31.9 \pm 1.8$ \\
Overall & $32.3 \pm 0.8$ & $32.2 \pm 1.7$ \\
\hline
\end{tabular}

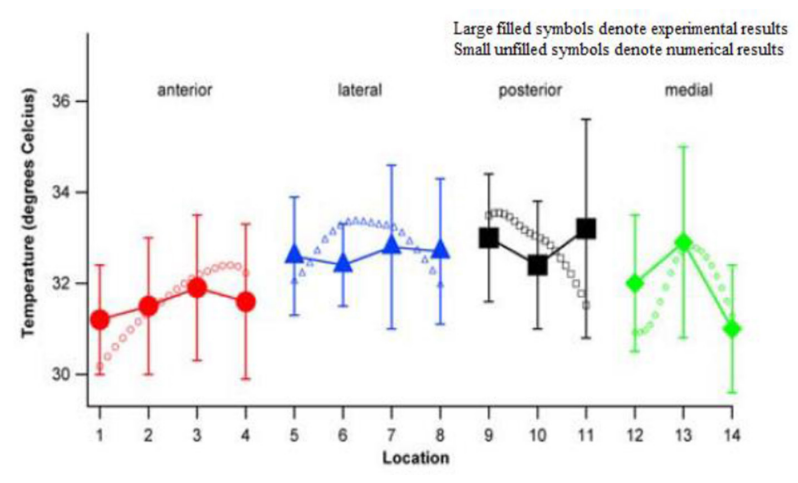

Figure 6: Skin temperature versus location for the numerical model and the experimentally acquired temperature data (mean value \pm standard deviation) [18]. 


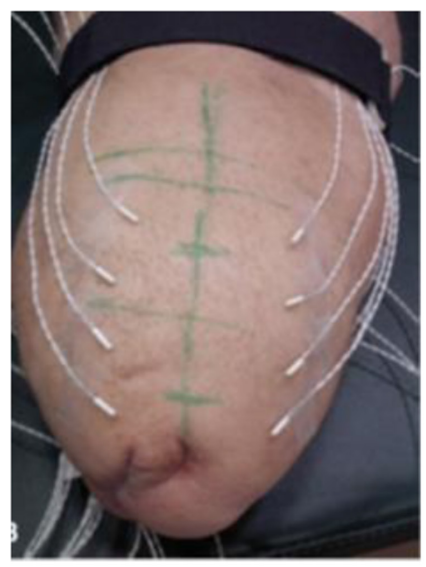

(a)

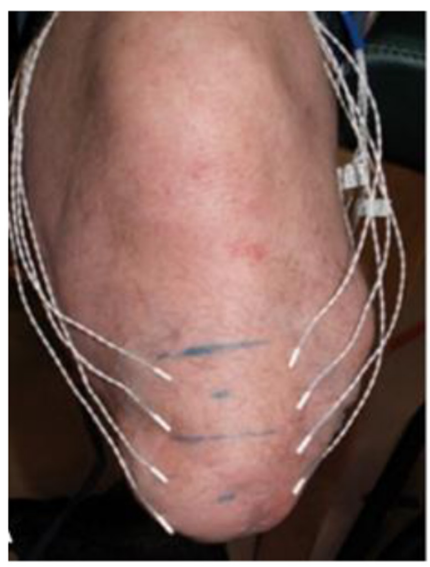

(b)

Figure 7: The placement of temperature sensors on a left residual limb (a) interior view (b) posterior view [18].

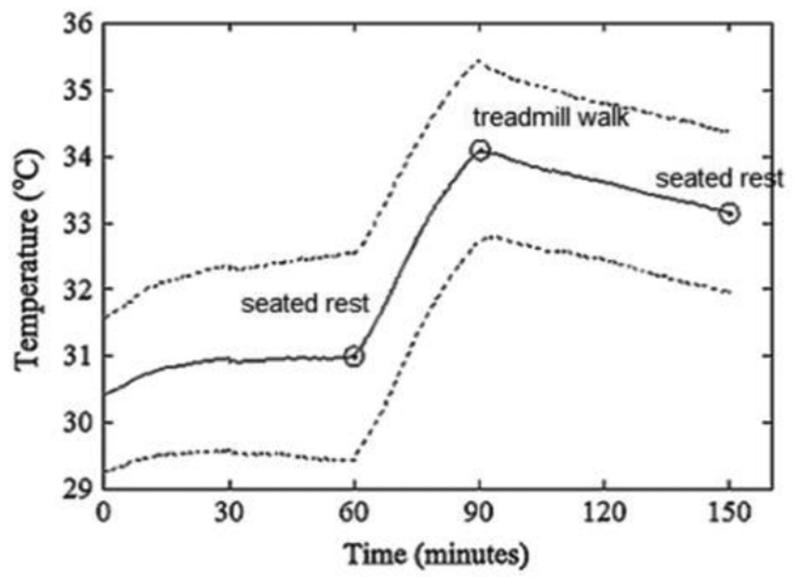

Figure 8: Mean (solid line) residual limb temperature versus time $( \pm 1$ degree $\mathrm{C}$ dotted lines) [18].

showed that activity increased the residual limb skin temperature rapidly. A 10-minute treadmill walk caused an increase about $0.8^{\circ} \mathrm{C}$ whereas a 30-minute tread-mill walk increased the temperature of limb about $3.1^{\circ} \mathrm{C}$. Figure 8 shows the variation of the mean residual limb skin temperature during $150 \mathrm{~min}$. The results showed that walk causes a significant increase in skin temperature inside the prosthesis. New prosthetic technology is needed to solve skin problems caused by the temperature increase due to different activities.

\section{DEVELOPMENT AND ENHANCEMENT OF PROSTHESES}

Rugh et al. [20] developed a tool to predict the human thermal comfort in transient, non-uniform thermal environments. A physiological model of the human body with heating and sweating and an empirical model were used to predict the local and global thermal situation 
and comfort. Baars and Geertzen [21] reviewed the advantages of silicon liner on prosthetic patients. The study recommended further use of objective clinical parameters to find advantages of the silicon liner socket in the transtibial prosthesis.

Isik [22] developed a heating system with a temperature ranging from $15^{\circ} \mathrm{C}$ to $50^{\circ} \mathrm{C}$ to be applied in cold weather conditions. The system was tested for patients who suffer from various illnesses and the results showed the thermoelectric foot wear system offered a good comfort design. Figure 9 shows the thermoelectric foot wear system.

Peery et al. [18] have shown that donning causes a moderate temperature increase and walking causes a significant increase. The resting state periods following activities must be substantially long to return the limb to the comfortable temperature. A thermal model of a transibial residual limb by Lee and Zhang [23] used a computational analysis to predict prosthetic socket fitness. It was suggested that further attempts should be made to allow computational analysis to be a useful tool for socket assessment. Davis and Hunter [24] studied threshold detection in upper limb amputees in a laboratory environment of $23^{\circ} \mathrm{C}$. Participants were asked to identify a warming sensation on bare skin with no prosthesis in response to a thermal stimulus that began at a baseline temperature of $32^{\circ} \mathrm{C}$ and then was increased by $0.5^{\circ} \mathrm{C}$. The study detected a warming sensation at $35.7^{\circ} \mathrm{C}$; an increase of $3.7^{\circ} \mathrm{C}$. It was concluded that this could be related to the amputation, but could also be related to the environment. Klute et al. [25] reviewed prosthetic liners and concluded that many choices in liner technology are available and the clinics often rely on personal intuition and experience to choose which liner is more appropriate for a patient. The results of this review suggest that liner material properties have been well studied but their influences on the performance are not well understood. Sanders et al. [26] developed a device using radio frequency to monitor sock use. Three patients were tested during sitting and walking activities. The sock can tell a patient via alarm, smartphone, message, or some other means.

Han et al. [27] presented a novel thermal management device to maintain a constant skin temperature for the lower limb prosthesis to decrease thermal resistance. A new cooling device was designed by using heat pipes to collect the heat generated from the residual limb and deliver the heat to a compact heat sink outside the socket. A small fan was used to remove heat from the heat sink. Figure 10 shows the cooling device prototype and the measurement set up.

Thermal management of the device was based on the adjustable thermal resistance of the heat sink ranging from $0.77^{\circ} \mathrm{C} / \mathrm{W}$ to $2.95^{\circ} \mathrm{C} / \mathrm{W}$. The cooling device required lower fan power level and lower power consumption with its compact size, quiet operation and capability

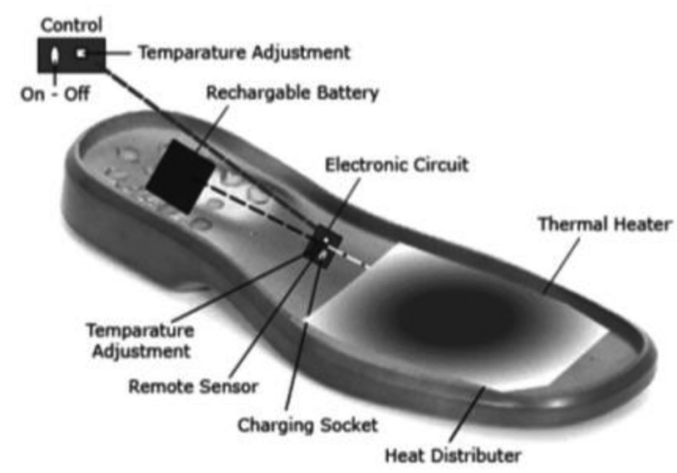

Figure 9: Foot wear system [21]. 


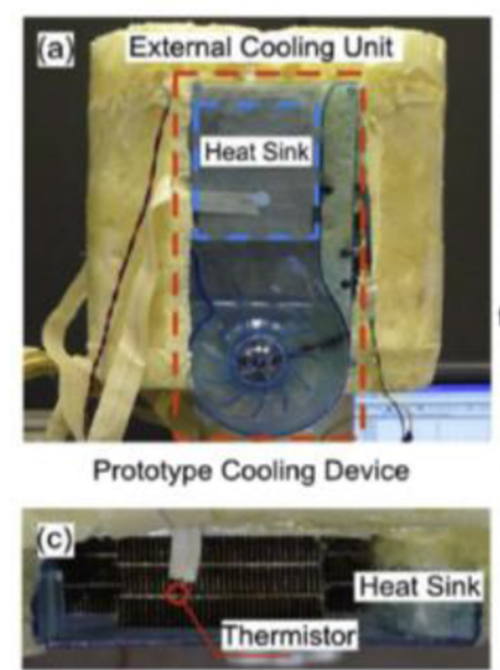

Top View

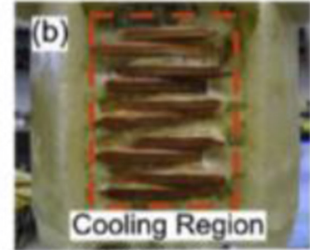

Without the External Cooling Unit

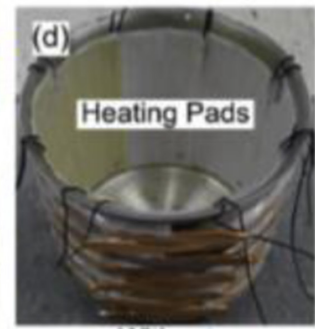

Without

the Insulation layer

Figure 10: Prototype of the air cooling device and the measurement set up [26].

of effectively removing the heat generated inside the socket. It is promising that the device might solve the thermal regulation problem for amputees wearing prostheses under various daily activities.

Webber and Davis [28] presented a design of a novel prosthetic socket. Two sockets were studied both experimentally and numerically. The first one was modelled as a control socket, and the second one was modelled as a modified socket with a helical cooling channel of diameter $0.48 \mathrm{~cm}$. Figure 11 shows three views for the socket and Figure 12 shows the experimental model. The results showed that the modified socket with a cooling channel has greater temperature difference across its wall. Figure 13 shows the temperature contours of the outer socket and the cross section for the two types of sockets. It can be seen that the modified socket containing a helical cooling channel achieved a greater temperature drop from

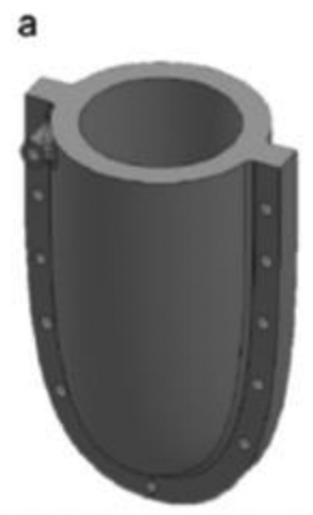

b

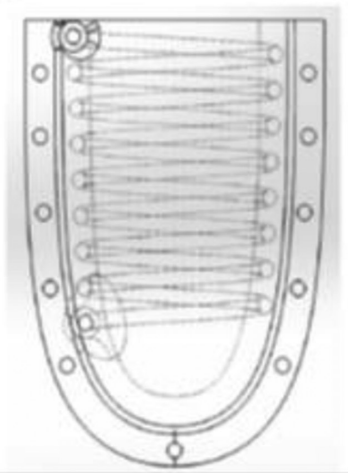

C

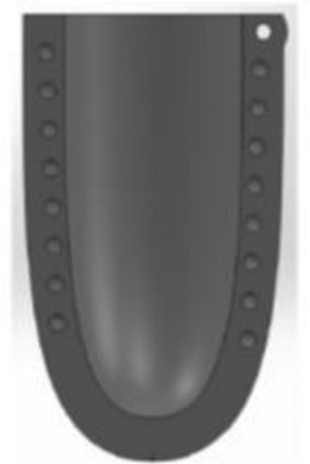

Figure 11: Modified socket in three views (a) trimetric view, (b) front view and (c) cross section view [28]. 


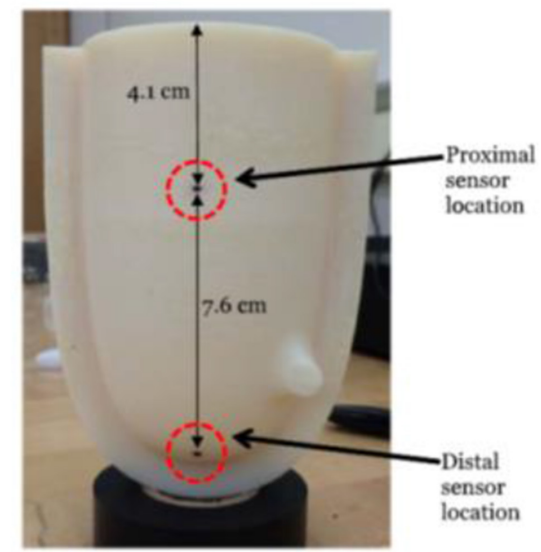

Figure 12: Experimental model with temperature sensor locations [28].

a

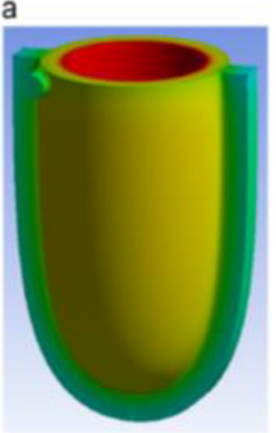

b

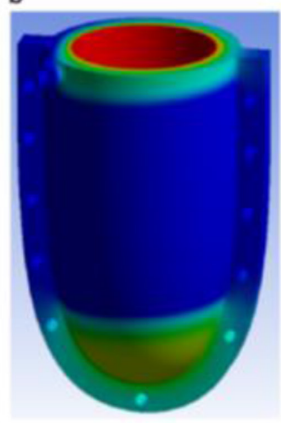

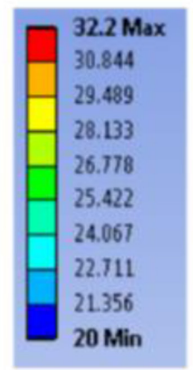

$\left({ }^{\circ} \mathrm{C}\right)$

Figure 13: Outer socket temperature contours of (a) the control socket (b) the modified socket using steady temperature input [28].

the inner socket surface to the outer surface. This work revealed that 3D printing may help to re-establish a comfortable environment around the residual limb in the socket. Thermal modelling combined with experimental measurements may help design and development of prosthetic sockets.

Han et al. [29] proposed an automatic control scheme. The system can maintain a desirable skin temperature at different thermal loads. The new design could be promising to minimize the heat and perspiration within a prosthetic socket.

\section{FUTURE REMARKS}

Thermal discomforts are side effects of prosthesis used in hot, cold and humid surroundings so it is important to control heat transfer of the prosthesis. The prosthesis is usually made of insulating materials, which limit heat transfer and promote perspiration, resulting in stump skin injuries. The solution to this problem is challenging. Several future research needs are listed below:

- New materials to be used for liner that could eliminate the abnormal thermal environment around the residual limb. 
- New cooling methods, e.g., design of helical cooling channels inside the socket or implementation of heat pipes to decrease thermal resistance.

- More realistic thermal modelling considering the heat generation in the residual limb due to thermoregulation of the body.

- Coupled thermal and mechanical modelling and validation with experiments at clinical conditions, which will aid novel design of prosthesis.

\section{REFERENCES}

[1] Webber, C., Prosthetic Sockets: Assessment of Thermal Conductivity, Master Dissertation, University of Akron, 2014.

[2] Bahraizadh, M., Below knee prosthesis, Department of Orthotics and Prosthetics slide player.com / slide / 4188530.

[3] Dickson orthotics and prosthetics, available at: www.dicksonop.com.

[4] Klute, G.K., Rowe, G.I., Mamishev, A.V. \& Ledous, W.R., The thermal conductivity of prosthetic sockets and liners. Prosthetics and Orthotics International, 31, pp. 292-299, 2007. http://dx.doi.org/10.1080/03093640601042554

[5] Peery, J.T., Ledoux, W.R. \& Klute, G.K., Residual limb skin temperature in transtibial sockets. Journal of Rehabilitation Research and Development, 42, pp. 147-154, 2005. http://dx.doi.org/10.1682/JRRD.2004.01.0013

[6] Ghoseiri, K. \& Safari, M.R., Prevalence of heat and perspiration discomfort inside prostheses: literature review. Journal of Rehabilitation Research and Development, 51, pp. 855-868, 2014.

http://dx.doi.org/10.1682/JRRD.2013.06.0133

[7] Barnes, G.H., Skin health and stump hygiene artificial limbs. In Selected Articles from Artificial Limbs, Krierger: Huntington, New York, 1970.

[8] Branemark, R. \& Hagberg, K., Consequences of non-vascular-femoral amputations: a survey of quality of life, prosthetic use and problems. Prosthetics and Orthotics International, 25, pp. 186-194, 2001.

http://dx.doi.org/10.1080/03093640108726601

[9] Hachiuska, K., Matsushima, Y., Ohmine, S. \& Shinkoda, K., Moisture permeability of the total surface bearing prosthetic socket with a silicon liner: is it superior to the patella-tendon bearing prosthetic socket? Archives of Physical Medicine and Rehabilitation, 82, pp. 1286-1289, 2001.

[10] Meulenbelt, H.E., Geertzen, J.H., Jonkman, M.F. \& Dijkstra, P.U., Determinants of skin problems of the stump in lower limb amputees. Archives Physical Medicine and Rehabilitation, 90, 74-81, 2009.

http://dx.doi.org/10.1016/j.apmr.2008.07.015

[11] Koc, E., Tunca, M., Akar, A., Erbil, H., Demiralp, B. \& Arca, E., Skin problems in amputees: a descriptive study. International Journal of Dermatology, 47, pp. 463-466, 2008. http://dx.doi.org/10.1111/j.1365-4632.2008.03604.x

[12] Calum, C., Lyon, M.A., Kulkarni, J., Zimerson, E. \& Beck, M.H., Skin disorders in amputees. Journal of the American Academy of Dermatology, 42, pp. 501-507, 2000. http://dx.doi.org/10.1016/S0190-9622(00)90227-5

[13] Gustavsson, M., Karawacki, E. \& Gustafsson, S.E., Thermal conductivity, thermal diffusivity, and specific heat of thin samples from transient measurements with hot disk sensors. Review of Scientific Instruments, 65, pp. 3856-3859, 1994.

http://dx.doi.org/10.1063/1.1145178 
[14] http://www.thermoconcept-sarl.com/index.php/en/thermal-analysis-ndt-systems/hotdisk-thermal-constants-analyzer/hot-disk-thermal-conductivity.

[15] Wissler, E.H., A mathematical model of the human thermal system. Bulletin of Mathematical Biophysics, 26, pp. 147-165, 1964.

http://dx.doi.org/10.1007/BF02476835

[16] Gordon, R.G., Roemer, R.B. \& Horvath, S.M., A mathematical model of the human temperature regulatory system-transient cold exposure response. IEEE Transaction on Biomedical Engineering, 6, pp. 434-444, 1976. http://dx.doi.org/10.1109/TBME.1976.324601

[17] Pennes, H.H., Analysis of tissue and arterial blood temperatures in the resting human foream. Journal of Applied Physiology, 1, pp. 93-122, 1948.

[18] Peery, J.T., Klute, G.K., Blevins, J.J. \& Ledoux, W.R., A three-dimensional finite element model of the transibial residual limb and prosthetic socket to predict skin temperatures. IEEE Transactions of Neural Systems and Rehabilitation Engineering, 14, pp. 336-343, 2006.

http://dx.doi.org/10.1109/TNSRE.2006.881532

[19] Klute, G.K. \& Ledoux, W.R., Does activity affect residual limb skin temperature? Clinical Orthopaedics and Related Research, 472, pp. 3062-3067, 2014.

http://dx.doi.org/10.1007/s11999-014-3741-4

[20] Rugh, J.P., Farrington, R.B., Vlahinos, A., Burke, R., Huizenga, C. \& Zhang, H., Predicting human thermal comfort in a transient none-uniform thermal environment. Journal of Applied Physiology, 92, pp. 721-727, 2004. http://dx.doi.org/10.1007/s00421-004-1125-2

[21] Baars, E.C.T. \& Geertzen, J.H.B., Literature review of the possible advantages of silicon liner socket use in trans-tibial prostheses. Prosthetics and Orthotics International, 29, pp. 27-37, 2005.

http://dx.doi.org/10.1080/17461550500069612

[22] Isik, H., Design and construction of thermoelectric footwear heating system for illness feet. Journal of Medical Systems, 29, pp. 627-631, 2005.[23] Lee, W.C.C. \& Zhang, M., Using computational simulation to aid in the prediction of socket fit: a preliminary study. Medical Engineering and Physics, 29, pp. 923-929, 2007.

[23] Davis, K.D. \& Hunter, J.P., Dissociation of phantom limb phenomena from stump tactile spatial acuity and sensory thresholds. Brain, 128, pp. 308-320, 2005.

[24] Klute, G.K., Glaister, B.C. \& Berge, J.S., Prosthetic liners for lower limb amputee: a review of the literature. Prosthetics and Orthotics International, 34, pp. 146-153, 2010. http://dx.doi.org/10.3109/03093641003645528

[25] Sanders, J.E., Murthy, R., Cagle, J.C., Allyn, K.J., Phillips, R.H. \& Otis, B.P., Device to monitor sock use in people using prosthetic limbs: technical report. Journal of Rehabilitation Research \& Development, 49, pp. 1229-1238, 2012.

[26] Han, Y., Liu, F., Dowd, G. \& Zhe, J., A thermal management device for a lower-limb prosthesis. Applied Thermal Engineering, 82, pp. 246-252, 2015.

http://dx.doi.org/10.1016/j.applthermaleng.2015.02.078

[27] Webber, C.M. \& Davis, B.L., Design of a novel prosthetics socket: assessment of the thermal performance. Journal of Biomechanics, 48, pp. 1294-1299, 2015. http://dx.doi.org/10.1016/j.jbiomech.2015.02.048

[28] Han, Y., Liu, F., Zhao, L. \& Zhe, J., An automatic and portable prosthetic cooling device with high cooling capacity based on phase change. Applied Thermal Engineering, 104, pp. 243-248, 2016.

http://dx.doi.org/10.1016/j.applthermaleng.2016.05.074 